\title{
Idea zrównoważonego rozwoju w świetle encykliki papieża Franciszka Fratelli tutti
}

\author{
The Idea of Sustainable Development in the Light of Pope Francis' Encyclical Fratelli tutti
}

\author{
Zbigniew Babicki \\ Instytut Pedagogiki, Uniwersytet Kardynała Stefana Wyszyńskiego w Warszawie \\ ORCID: https://orcid.org/0000-0002-0857-3132・z.babicki@uksw.edu.pl \\ Zgłoszono: 11.03.2021; zrecenzowano: 20.05.2021; zaakceptowano do druku: 24.05.2021
}

Streszczenie: W artykule przedstawione zostały w ogólnym zarysie idee zrównoważonego rozwoju i społeczne nauczanie papieża Franciszka zawarte w encyklice Fratelli tutti. Bardzo ważnym wymiarem założeń zrównoważonego rozwoju jest konstruowanie wzorca życia społecznego. Chodzi tu o takie sposoby działań, które będą umożliwiały rozwiązywanie konfliktów społecznych, zwłaszcza w sytuacjach rozwarstwiania się społeczeństwa. Papież Franciszek w encyklice Fratelli tutti, która mówi o braterstwie i przyjaźni społecznej, upomina się o humanistyczne relacje między ludźmi. Zaniepokojony o przyszłość człowieka proponuje skorzystanie z możliwości, jakie niesie przesłanie powszechnego braterstwa i przyjaźni społecznej, które będzie podstawą w budowaniu wspólnoty ludzkiej i ładu społecznego. Artykuł zwraca uwagę na konieczność połączenia wysiłków i współpracy na rzecz realizacji celów humanistycznego rozwoju ludzkości, czyli na zrównoważoną zmianę. Celem tego artykułu jest refleksja nad ideą zrównoważonego rozwoju w kontekście społecznego nauczania papieża. Jeśli bowiem diagnoza zagrożeń współczesnego świata, jak również remedium na te zagrożenia w postaci edukacji dla zrównoważonego rozwoju są w jakiejś mierze zbieżne z głosem Kościoła, oznaczać to może wspólne pole do działania na rzecz poprawy sytuacji. Istnieje uzasadniona i pilna potrzeba zarówno teoretycznych odniesień do kryzysowych zjawisk i tendencji, jak i realnych działań, które przyczynią się do eliminowania i niwelowania zgubnych procesów dla środowiska społecznego oraz przyrodniczego naszej planety. Nadszedł czas współdziałania na płaszczyźnie edukacji zmierzającej do budowania na świecie powszechnego braterstwa i przyjaźni społecznej, która daje możliwość podejmowania celów zrównoważonego rozwoju. Dzięki współpracy wszystkich ludzi dobrej woli cele zrównoważonego rozwoju przybliżają się do konkretnych ludzi, stając się ich własnym zadaniem do wykonania. Idea zrównoważonego rozwoju zyskuje ważnego sojusznika w postaci edukacyjnego wsparcia ze strony papieża Franciszka i jego wizji świata opartego na braterstwie i przyjaźni społecznej. Jest to wizja świata odwołująca się do obowiązku miłości bliźniego, troski o integralny rozwój człowieka i ostatecznie o jego zbawienie. Z pewnością każda próba konfrontowania idei zrównoważonego rozwoju z nauczaniem społecznym papieża Franciszka, zawartym przede wszystkim w encyklice Fratelli tutti, będzie zależała od przyjmowanego światopoglądu oraz wizji rozwoju człowieka i świata. Tym, co łączy te dwie propozycje, jest jednak zatroskanie o dobro ludzkości i naszej planety.

Słowa kluczowe: zrównoważony rozwój, sprawiedliwość, solidarność społeczna, braterstwo, przyjaźń społeczna

\footnotetext{
Abstract: The article presents an overview of the ideas of sustainable development and the social teachings of Pope Francis contained in the encyclical Fratelli tutti. A very important dimension of sustainable development assumptions is constructing a pattern of social life. It is about methods of action that will make it possible to solve social conflicts, especially in situations of social stratification. Pope Francis, in the encyclical Fratelli tutti, which talks about fraternity and
} 
social friendship, advocates for humanistic relations between people. Concerned about the human future, he proposes to take advantage of the opportunities offered by the message of universal brotherhood and social friendship, which will be the basis for building a human community and social order. The article draws attention to the necessity to combine efforts and cooperation to achieve the goals of humanistic development of humanity, i.e., sustainable change. The purpose of this article is to reflect on the idea of sustainable development in the context of the pope's social teaching. For if the diagnosis of the threats to the modern world, as well as the remedy for these threats in the form of education for sustainable development, to some extent coincide with the voice of the Church, this may mean a common field for action to improve the situation. There is a justified and urgent need for both theoretical references to crisis phenomena and tendencies, as well as real actions that will contribute to the elimination and elimination of disastrous processes for the social and natural environment of our planet. The time has come to cooperate in the field of education aimed at building universal brotherhood and social friendship in the world, which gives the opportunity to undertake the goals of sustainable development. Thanks to the cooperation of all people of good will, the goals of sustainable development come closer to specific people, becoming their own task to be performed. The idea of sustainable development gains an important ally in the form of educational support from Pope Francis and his vision of a world based on brotherhood and social friendship. It is a vision of the world referring to the duty of love for one's neighbor, care for the integral development of man and ultimately for his salvation. Certainly, any attempt to confront the idea of sustainable development with the social teaching of Pope Francis, included above all in the encyclical Fratelli tutti, will depend on the adopted worldview and vision of human and world development. However, what these two propositions have in common is concern for the welfare of mankind and our planet.

Keywords: sustainable development, justice, social solidarity, fraternity, social friendship

\section{Wstęp}

Współczesny świat charakteryzuje się intensywną działalnością człowieka, która wpływa na oblicze naszej planety. Stworzona przez niego cywilizacja w istotny sposób zakłóca równowage Ziemi. Ponadto w tym dynamicznie rozwijającym się świecie coraz wyraźniej widać zagubienie człowieka, zaburzenie równowagi w relacjach społecznych, brak wystarczającej troski o dobra kultury, niepewność ludzkiej przyszłości, brak sensu egzystencji. Wartość człowieka często mierzy się jego rynkową aktywnością i użytecznością. Zasady wolnorynkowe odciskają piętno na innych sferach ludzkiej egzystencji. W miejsce humanistycznej wizji człowieka wkrada się prosta kalkulacja: zysk-strata, wygrany-przegrany, sukces, bogactwo materialne, bezrefleksyjna konsumpcja itp. Rozwój osiągnięć cywilizacyjnych idzie w parze z podporządkowaniem kulturowym, gdzie relacje na zasadach opłacalności powodują odhumanizowanie życia poszczególnych ludzi. Dlatego też należy przeciwstawiać się traktowaniu człowieka przedmiotowo, szacowaniu na zasadach opłacalności. Takie głosy wybrzmiewają w idei zrównoważonego rozwoju, jak też w nauczaniu społecznym Kościoła katolickiego. W imieniu Kościoła wypowiada się jego głowa, papież Franciszek, m.in. w społecznej encyklice Fratelli tutti.

Celem tego artykułu jest refleksja nad ideą zrównoważonego rozwoju w kontekście społecznego nauczania papieża. Jeśli bowiem diagnoza zagrożeń współczesnego świata, jak również remedium na te zagrożenia w postaci edukacji dla zrównoważonego rozwoju są w jakiejś mierze zbieżne z głosem Kościoła, oznaczać to może wspólne pole do działania na rzecz poprawy sytuacji. Istnieje uzasadniona i pilna potrzeba teoretycznych odniesień do kryzysowych zjawisk i tendencji, które przyczynią się do eliminowania i niwelowania zgubnych procesów dla środowiska społecznego oraz przyrodniczego naszej planety. W artykule poruszane są wybrane obszary wspólne dla idei zrównoważonego rozwoju i społecznego nauczania Kościoła katolickiego. 


\section{Idea zrównoważonego rozwoju a przesłanie braterstwa i przyjaźni społecznej w ujęciu papieża Franciszka}

Pojęcie zrównoważonego rozwoju jest mało precyzyjne, a co za tym idzie, przynosi wiele trudności z jego rozumieniem i wyjaśnieniem, ponieważ odnosi się, m.in. do różnych obszarów ludzkiej egzystencji, np. ekologicznego, ekonomicznego czy społeczno-kulturowego. Nie wchodząc w polemikę z różnymi koncepcjami tego pojęcia, przyjąłem powszechnie używaną definicję zrównoważonego rozwoju sformułowaną w 1987 r. w raporcie Nasza wspólna przyszłość Światowej Komisji Środowiska i Rozwoju ONZ, która określa go jako „proces mający na celu zaspokojenie aspiracji rozwojowych obecnego pokolenia w sposób umożliwiający realizację tych samych dążeń następnym pokoleniom" (Światowa Komisja ds. Środowiska i Rozwoju 1991). Wyłaniający się z tej definicji zrównoważony rozwój odnosi się do kwestii ekologicznych (ochrony środowiska), racjonalnej eksploatacji zasobów naturalnych, jak też rozwoju społecznego (dostęp do edukacji, walka z biedą czy ochrona zdrowia). Idea zrównoważonego rozwoju jest dzisiaj często utożsamiana z przestrzeganiem pewnego zbioru zasad. Małgorzata Burchard-Dziubińska wskazuje, że zbiór ten jest mniej lub bardziej rozbudowany, jednak „powszechnie zwraca się uwagę na kilka kwestii, a mianowicie na spoczywający na państwach obowiązek zapewnienia zrównoważonego użytkowania zasobów naturalnych, sprawiedliwość i wykorzenienie ubóstwa, wspólną, lecz zróżnicowaną odpowiedzialność, przezorność w podejściu do zdrowia ludzkiego, do zasobów naturalnych i ekosystemów, partycypację społeczną oraz dostęp do informacji i wymiaru sprawiedliwości, a także na dobre rządzenie" (Burchard-Dziubińska 2014, 22). Wiedza z zakresu przywołanych tutaj zagadnień zidentyfikowanych jako zrównoważony rozwój wymaga podejmowania działań edukacyjnych, które będą przygotowywać ludzi do funkcjonowania w zglobalizowanych społeczeństwach.
Papież Franciszek, dokonując diagnozy współczesnego świata, a przy tym zainspirowany wezwaniem "fratelli tutti” św. Franciszka z Asyżu, który w ten sposób zwracał się do wszystkich braci i sióstr, proponując im formę życia o zabarwieniu ewangelicznym, pragnie ożywić wśród wszystkich współcześnie żyjących ludzi powszechne pragnienie braterstwa. W społecznej encyklice Fratelli tutti, która traktuje o braterstwie i przyjaźni społecznej, upomina się o humanistyczne relacje między ludźmi. Zaniepokojony o przyszłość człowieka proponuje skorzystanie z możliwości, jakie niesie przesłanie powszechnego braterstwa i przyjaźni społecznej, które będzie podstawą w budowaniu wspólnoty ludzkiej. Podkreśla, że zagadnienia związane z przyjaźnią społeczną i braterstwem zawsze leżały w centrum jego trosk. Mówił o tym już wcześniej: „Potrzebujemy wspólnoty, ażeby nas wspierała, pomagała nam, takiej, w której pomagamy sobie nawzajem patrzeć w przyszłość" (Franciszek 2019a, 27). Papież widzi w tym przesłaniu narzędzie służące do zmiany stylu życia i postaw, odbudowę środowiska egzystencji człowieka na zasadzie współistnienia opartego na przyjaźni społecznej i braterstwie. Z podobnym przesłaniem mamy do czynienia w idei zrównoważonego rozwoju, którą należy rozwijać i realizować w kontekście paradygmatu współistnienia i braterstwa.

Analizując ideę zrównoważonego rozwoju i społeczne nauczanie obecnego papieża, który jest głosem Kościoła powszechnego, można wyodrębnić pewne wspólne obszary życia współczesnego człowieka i preferowane kierunki rozwoju społeczno-ekonomicznego. Warto podkreślić, że nauczanie Franciszka nie jest wcale rewolucyjne w swojej wymowie, ale jest kontynuacją i rozwinięciem myśli jego poprzedników.

\section{Rozwój cywilizacji i potrzeba budowy nowego ladu społecznego}

We współczesnym świecie splatają się różnego rodzaju mega wpływy: ideologiczne, społeczno-kulturowe, technologiczne, 
gospodarcze, rynkowe. Zakres i intensywność tych procesów sprawiają, że tworzą się nowe, globalne reguły i mechanizmy rządzące światem. Prowadzą one do zauważalnych dychotomii w życiu jednostek, grup społecznych i całych społeczeństw. Z jednej strony postępująca i chyba już nieodwracalna współzależność gospodarcza czy społeczno-kulturowa, z drugiej zaś widoczny kryzys, a nawet atrofia więzi międzyludzkich, fragmentaryzacja i relatywizacja życia etycznego, rozpad tożsamości. Na tym tle tworzy się i funkcjonuje nowe środowisko (wychowawcze) człowieka. W wymiarze społeczno-kulturowym, jak zauważa Wiesław Theiss, globalizacja współtworzy bliższe, bezpośrednie i pośrednie środowisko życia jednostek i szerszych grup społecznych. W takiej sytuacji ujawnia się potrzeba dążenia do tego, aby to środowisko było jak najbardziej „[...] bezpieczne, tzn. takie, w którym ludzie wiedzą jak postępować, i aby nie zagrażało ono podmiotowości i tożsamości człowieka, należy obecny świat zrozumieć oraz przygotować do funkcjonowania w nim. Dlatego jednym z głównych zadań szeroko rozumianej edukacji jest ograniczenie niebezpieczeństw, które grożą człowiekowi ze strony różnych i sprzecznych, bardzo intensywnych globalnych wpływów, a z drugiej strony optymalne wykorzystanie nieograniczonych wręcz szans i możliwości rozwojowych, jakie przynosi globalizacja" (Theiss 2016, 18-19).

Nie ulega wątpliwości, że człowiek ma prawo do rozwoju, zarówno w wymiarze jednostkowym, jak i społecznym. Jak zauważa W. Theiss, rozwój społeczny traktowany jakościowo i personalistycznie ma swoje źródło w świadomości oraz uznaniu potrzeb własnych i innych ludzi (bliźnich). Polega on, zdaniem autora, na „tworzeniu związków między ludźmi, a jego warunkiem jest solidarność z innymi. Etyczny oraz wspólnotowy wymiar rozwoju sprawia, że nie jest on po prostu mechaniczną realizacją «dobrego celu». Dobro, do którego dąży rozwój, nie należy bowiem do obszaru celów rozwoju, lecz do obszaru działania i motywów tego działania. Stąd tak rozumiany rozwój jest cnotą moralną, cnotą ludzi. Widoczny dziś w globalnym świecie brak rozwoju to deficyt cnoty, brak woli uczestnictwa w dziele stwarzania, brak świadomości współzależności, brak ducha prawdziwej solidarności" (Theiss 2004, 100).

Podłożem problemów i zagrożeń wynikających z rozwoju cywilizacji jest niekontrolowane dążenie człowieka do zaspokajania coraz to nowych potrzeb cywilizacyjnych za cenę realizacji potrzeb biologicznych i społecznych, przy jednoczesnym zachowaniu najniższych nakładów finansowych. Ten szkodliwy kierunek zmian cywilizacyjnych można zahamować poprzez budowanie i realizowanie nowego wzorca rozwoju cywilizacyjnego, który z jednej strony nie zaburzałby równowagi ekologicznej, a z drugiej strony pozwoliłby na utrzymanie wysokiego poziomu życia i rozwoju wszystkich społeczeństw. Istotnym warunkiem przetrwania ludzkości i dalszego rozwoju jest zmiana stylu życia i dostosowanie wzrostu gospodarczego do wydolności środowiska. Można tego dokonać za pomocą tych samych mechanizmów, którym zawdzięczamy rozwój obecnej cywilizacji naukowej i technicznej, a także przekraczania przyrodniczych ograniczeń. Wydaje się, że modelem rozwoju spełniającym wymienione tu kryteria jest idea zrównoważonego rozwoju. Współczesny człowiek, budując na jego koncepcji procesy globalnego rozwoju społecznego, technologicznego i gospodarczego, będzie miał możliwość powstrzymać zagrożenia destrukcyjnie wpływające na dalszy rozwój cywilizacyjny (Skowroński 2006, 50).

Rozwój cywilizacji z jednej strony przynosi wiele dobrych skutków dla człowieka, z drugiej - ułatwia zapominanie, że człowiek sam jest członkiem szerszej wspólnoty oraz częścią przyrody i żyje w jej środowisku. Koncepcja przemian, znana jako idea zrównoważonego rozwoju, zwraca uwagę na nieproporcjonalność tempa pojawiania się zagrożeń dla ludzkiego zdrowia i tempa podnoszenia się poziomu społecznej świadomości tych zagrożeń. Oddziaływanie człowieka na środowisko przyrodnicze przynosi wiele 
negatywnych skutków, z których część stanowi realne zagrożenie dla zdrowia, a może i przetrwania ludzkiego gatunku. Dobrze widać to chociażby na przykładzie kryzysu klimatycznego. Zanieczyszczenia środowiska, stanowiące źródło tego kryzysu, są wdzięcznym tematem medialnym, ale wciąż trudno o działania, które by im zaradzały, a tym samym lepiej chroniły zdrowie i komfort życia człowieka. Refleksja nad zagrożeniami spowodowanymi dynamicznym rozwojem społeczno-gospodarczym dostarcza coraz więcej argumentów przemawiających za potrzebą edukacji na rzecz zrównoważonego rozwoju. Zagrożenia te mają odmienny charakter i różne czynniki leżą u ich podłoża. Jednym razem są wynikiem przenikających się wpływów nowych technologii i ideologii, tworząc tym samym nowe, zarazem globalne mechanizmy rządzące współczesnym światem. Innym razem odnoszą się do problematyki ochrony środowiska, wskazując na kryzysową sytuację ekologiczną współczesnego świata. Coraz większa świadomość tych zagrożeń odsłania skalę wyzwań, przed którymi staje dzisiejszy zglobalizowany świat i cywilizacja. Niekontrolowany rozwój cywilizacji pociąga za sobą niepokojące konsekwencje w sferze bytowej człowieka, co najwyraźniej widać na przykładzie coraz bardziej rozwarstwiających się społeczeństw i braku możliwości integralnego rozwoju znacznej części ludności.

Papież Franciszek zauważa, że istnieją zasady ekonomiczne, które okazały się skuteczne dla rozwoju ekonomicznego, chociaż nie $\mathrm{w}$ tej samej mierze dla integralnego rozwoju człowieka. Wzrosło bogactwo, ale pozbawione równości, co prowadzi do powstawania "nowych form ubóstwa" (Franciszek 2020, 17). Jan Paweł II przestrzegał, że rozwój nie może być podporządkowany coraz większemu gromadzeniu dóbr przez nielicznych. Ponieważ „taki model rozwoju, który by nie szanował i nie popierał praw ludzkich, osobistych i społecznych, ekonomicznych i politycznych, łącznie $z$ prawami narodów i ludów, nie byłby godny człowieka. Dzisiaj może wyraźniej niż kiedykolwiek dostrzega się wewnętrzną sprzeczność rozwoju ograniczonego tylko do dziedziny gospodarczej, łatwo podporządkowuje on osobę ludzką i jej najgłębsze potrzeby wymogom planowania gospodarczego lub wyłącznego zysku" (Jan Paweł II 1988, 33).

We współczesnym świecie utrzymują się liczne formy niesprawiedliwości wzmacniane przez zawężające koncepcje antropologiczne, jak też przez model gospodarczy budowany na zysku, który nie waha się wykorzystywać, odrzucać, a nawet zabijać człowieka. „Podczas gdy pewna część ludzkości żyje w dostatku, pozostała część doświadcza tego, że jej godność jest nieuznawana, pogardzana bądź deptana, a jej podstawowe prawa są ignorowane lub pogwałcane" (Franciszek 2019b, 25). Papież, mając na uwadze sprawczość i godność osoby ludzkiej, przekonuje, że każdego dnia otrzymujemy nową szansę, nowy etap. Nie powinniśmy zatem oczekiwać wszystkiego od tych, którzy nami rządzą - to byłoby zbyt infantylne. Należy cieszyć się przestrzenią współodpowiedzialności zdolną do inicjowania i generowania nowych procesów i transformacji. „Niech inni dalej myślą o polityce lub ekonomii w swoich grach o władzę. Umacniajmy to, co jest dobre i oddawajmy się służbie dobru. Można zaczynać od dołu i, przypadek po przypadku, walczyć o to, co jest najbardziej konkretne i lokalne, aż po najdalszy zakątek kraju i świata" (Franciszek 2020, 55). Trzeba stawiać sobie pytania o to, w jaki sposób i przy pomocy jakich inicjatyw można (od)budować wspólnotę, począwszy od osób, które utożsamiają się z kruchością drugiego człowieka, które nie godzą się na budowanie społeczeństwa wykluczenia, ale stają się bliźnimi, podnosząc upadłych i przywracając ich społeczeństwu dla wspólnego dobra. Wydaje się, że odpowiedzi na takie pytania można poszukiwać w potrzebie gruntownej edukacji, która będzie kształtować postawy dobra wspólnego i budować wspólnotę międzyludzką opartą na wzajemnej solidarności. 


\section{Społeczeństwa oparte na międzyludzkiej solidarności}

Idea zrównoważonego rozwoju promuje także zasadę kultury solidaryzmu w obrębie wspólnoty międzynarodowej. Chodzi tutaj o gotowość dzielenia się dobrami mieszkańców z krajów rozwiniętych, tzw. Globalnej Północy, z mieszkańcami Globalnego Południa. Na konieczność kształtowania postaw solidarności zwraca uwagę również Organizacja Narodów Zjednoczonych. Deklaracja Milenijna ONZ określa solidarność międzynarodową jako ,jedną z podstawowych wartości w stosunkach międzynarodowych w XXI wieku, gdzie ci, którzy cierpią bądź odnoszą w istniejącym porządku gospodarczym mniejsze korzyści, zasługują na pomoc tych, którzy odnoszą największe korzyści. Stąd w kontekście globalizacji i wyzwania, jakim są wzrastające nierówności, wspieranie idei międzynarodowej solidarności jest nieodzowne" (ONZ 2000, 2). Propagowanie solidarności globalnej i podnoszenie świadomości w zakresie współodpowiedzialności za jakość życia innych ludzi jest istotnym zadaniem edukacji na rzecz zrównoważonego rozwoju. Wartość globalnej solidarności, tzn. odpowiedzialności za innych, przejawia się poczuciem powinności wobec drugiego człowieka.

Konstruowanie wzorca życia społecznego opartego na idei solidarności międzyludzkiej jest bardzo ważnym wymiarem założeń zrównoważonego rozwoju. Chodzi tu o takie sposoby działań, które będą umożliwiały rozwiązywanie konfliktów społecznych, zwłaszcza w sytuacjach rozwarstwiania się społeczeństwa. Tadeusz Pilch zwraca uwagę, że dominująca współcześnie filozofia neoliberalnego rozwoju społeczeństw rodzi niedomogi i zagrożenia dla życia społecznego. Zasada rywalizacji, jako naczelna reguła neoliberalnego rynku, przeniesiona na grunt relacji międzyludzkich tworzy egoizm, ucieczkę od współdziałania, zrywa więzi międzyosobowe, powoduje obojętność na humanitarne konteksty zdarzeń i procesów, lekceważy szerszą perspektywę rozwoju czy buduje „ubóstwo w powiązania międzyludzkie" (Pilch 2013, 11-13). W związku z powyższą diagnozą istnieje realna potrzeba budowania takiego systemu społecznego, który umożliwiałby zapobieganie konfliktom wynikającym z nieharmonijnego, czyli niezrównoważonego rozwoju jednostek i społeczności (Kronenberg i Bergier 2010, 377).

W podobnym tonie wypowiada się Kościól, zwracając uwagę na potrzebę budowania społeczeństw w duchu solidarności społecznej. W obliczu wielu kryzysów, które chociażby prowadzą do śmierci z głodu miliony dzieci wycieńczonych ubóstwem i głodem, w dalszym ciągu na poziomie międzynarodowym panuje milczenie, z którym nie można się pogodzić. W tym kontekście, jak zaznacza Papież, choć należy być urzeczonym wieloma postępami, to jednak trudno tam dostrzec prawdziwie ludzki kurs (Franciszek 2020, 23). Papież wyraża swój niepokój także wobec faktu, że w dzisiejszym świecie poczucie przynależności do tej samej wspólnoty ludzkiej słabnie, a marzenie o wspólnym budowaniu sprawiedliwości i pokoju wydaje się być utopią z innej epoki. „W tym świecie, który biegnie bez wspólnego kursu, oddychamy atmosferą, w której dystans między obsesyjnym dążeniem do własnego dobrobytu a wspólnym szczęściem ludzkości zdaje się powiększać - skłania wręcz do myślenia, że między jednostką a społecznością ludzką następuje już prawdziwy rozłam" (Franciszek 2020, 24). Jeśli człowiek nie zdoła odzyskać chęci wspólnego budowania wspólnoty przynależności i solidarności, której należy poświęcić czas, wysiłek i dobra, łudząca nas globalna iluzja rozsypie się i pozostawi wielu ludzi w poczuciu nicości i pustki.

Jak przekonuje Franciszek, tylko miłość, znajdująca się w samym centrum życia społecznego i politycznego, jest zawsze miłością preferencyjną względem najmniejszych, motywującą wszystkie działania podejmowane na ich rzecz. Tylko spojrzenie, którego perspektywa została przekształcona miłością, prowadzi do pojęcia godności drugiego człowieka. Chodzi o to, że ubodzy są 
uznani i docenieni w ich niezmiernej godności, poszanowani w swoim własnym stylu i kulturze, a zatem prawdziwie włączeni w społeczeństwo. Takie spojrzenie jest fundamentem autentycznego ducha polityki. Zapoczątkowane w nim drogi różnią się od bezdusznego pragmatyzmu. Człowiek może pomagać potrzebującemu, ale kiedy razem $\mathrm{z}$ innymi tworzy społeczne procesy braterstwa i sprawiedliwości dla wszystkich, wkracza na „pole największej miłości, miłości politycznej”. Chodzi o postępowanie w drodze ku ładowi społecznemu i politycznemu, którego duszą jest miłość społeczna (Franciszek 2020, 125-126). Dlatego Papież przekonuje, że „nie można zmierzyć się ze skandalem ubóstwa, promując strategie redukcyjne, które jedynie uspokajają ubogich i przemieniają ich w osoby oswojone i nieszkodliwe. Jakie to smutne, kiedy widzimy, że pozornie altruistyczne akcje służą sprowadzaniu innych do bierności” (Franciszek 2014, 45). Potrzeba różnych dróg ekspresji i uczestnictwa w życiu społecznym - temu procesowi służy edukacja, aby każdy człowiek mógł stać się kowalem swojego losu. Tutaj ukazuje swoją wartość zasada pomocniczości, nierozłącznie związana z zasadą solidarności (Franciszek 2020, 131).

Budowanie społeczeństwa solidarnego z innymi ludźmi, zwłaszcza ze słabszymi, wymaga wchodzenia na drogę dialogu. Zróżnicowany pod wieloma względami świat potrzebuje jednostek, które będą potrafiły podejmować dialog z sobą samym i innymi ludźmi, którzy reprezentują także odmienne kultury. Aneta Rogalska-Marasińska zauważa, iż dialog z drugim człowiekiem powoduje, „że nie tylko myślimy z kimś, ale też podejmujemy trud myślenia dla kogoś, a nie przeciw komuś. Myślenie dialogiczne buduje partnerstwo, dąży do wspólnoty i tym samym osłabia postawę egoistyczną. Daje szansę na dostrzeżenie drugiego człowieka, a dzięki niemu - odczytanie na nowo siebie samego" (Rogalska-Marasińska 2017, 39).

Franciszek, przekazując encyklikę Fratelli tutti, proponuje, abyśmy w obliczu różnorodnych aktualnych problemów społecznych potrafili odpowiedzieć na nie nowym marzeniem o braterstwie i przyjaźni społecznej, nie ograniczając się jedynie do słów. I chociaż napisał ją, wychodząc od przekonań chrześcijańskich, które go ożywiają i karmią, starał się to uczynić w taki sposób, aby to przesłanie było otwarte na dialog ze wszystkimi ludźmi dobrej woli (Christiansen 2021, 6-13). Papież zauważa, że zbyt często współczesny człowiek jest bardzo skoncentrowany na własnych potrzebach i dostrzeżenie kogoś cierpiącego denerwuje go, przeszkadza mu, ponieważ nie chce marnować swojego czasu z powodu czyichś problemów. Takie objawy są w jego przekonaniu przejawem chorego społeczeństwa, ponieważ usiłuje ono rozwijać się na ludzkim cierpieniu (Franciszek 2020, 47).

\section{Edukacja dla zrównoważonego rozwoju}

Przyjmując założenie, że zrównoważony rozwój oznacza proces mający na celu zaspokojenie aspiracji rozwojowych obecnego pokolenia, w sposób umożliwiający realizację tych samych dążeń następnym pokoleniom, biorę pod uwagę następstwa takiego podejścia. Mianowicie, zawarta w tej koncepcji wizja rozwoju uwzględnia zarówno populację ludzką, jak i świat zwierząt i roślin, ekosystemy, zasoby naturalne ziemi: wodę, powietrze, surowce energetyczne, a także w sposób zintegrowany traktuje najważniejsze wyzwania stojące przed światem, takie jak walka z ubóstwem, prawa człowieka i jego bezpieczeństwo, edukacja dla wszystkich, zdrowie, dialog międzykulturowy. Aby sprostać tym wyzwaniom potrzebna jest rzetelna edukacja dla zrównoważonego rozwoju, która będzie oznaczać o wiele więcej niż tylko edukację ekologiczną. Będzie obejmować także: prawa człowieka, rozwiązywanie konfliktów, dobre rządy, gospodarkę, kulturę i sztukę. Edukacja dla zrównoważonego rozwoju oznacza zatem interdyscyplinarne podejście do kształcenia oferujące wszystkim ludziom, we wszystkich kontekstach edukacyjnych i we wszystkich fazach życia okazję do nauki takiego stylu życia, który zapewni im trwały rozwój. Oznacza 
to także, że edukacja dla zrównoważonego rozwoju będzie wykraczać daleko poza formalne systemy edukacyjne, natomiast powinna wywierać na nie wpływ, znajdując odzwierciedlenie w podręcznikach, programach i metodach nauczania.

Edukacja dla zrównoważonego rozwoju integruje edukację na rzecz ochrony środowiska (ekologiczną) zmierzającą do zmiany zachowań jednostek i społeczeństw oraz edukację globalną podkreślającą pilną potrzebę dokonywania głębokich zmian społecznych. Innymi słowy edukacja dla zrównoważonego rozwoju wyrasta z edukacji ekologicznej i edukacji globalnej, łącząc różne strategie edukacyjne badające zagadnienia rozwoju (społecznego). Przemysław Wielgosz zauważa, że dominujący model rozwoju już dawno ujawnił swoje głębokie ograniczenia. W miarę jak Wall Street czy City notowały kolejne spektakularne rekordy indeksów giełdowych, w tym samym czasie diagnozowano inne rekordy na skali nierówności, skrajnego ubóstwa, wykluczenia. Przywołany autor stwierdza, że „to, co w ekonomicznych teoriach i politycznych programach miało być jedynie tymczasowym kosztem wzrostu, okazało się jego trwałym rewersem, a dla rosnącej wciąż większości po prostu jego jedynym znanym obliczem" (Wielgosz 2010, 5).

Tak sformułowane oczekiwania społeczne są możliwe do realizacji przy założeniu, że edukacja dla zrównoważonego rozwoju zostanie oparta na określonych wartościach (społecznych). Podmiotowe uczestnictwo człowieka w urzeczywistnianiu zrównoważonego rozwoju wyraża się w planowaniu, organizowaniu, realizowaniu i weryfikowaniu działania w środowisku społecznym. Działania zmierzające do zmiany rzeczywistości, ulepszania świata na bazie idei zrównoważonego rozwoju często wymagają przewartościowania w postrzeganiu osoby ludzkiej i jej otoczenia. Oznaczać to może przyjęcie założeń odnoszących się do potrzeby kształtowania takich cech osobowości, jak: empatia, wrażliwość na potrzeby drugiego człowieka, postawa miłości do innych (caritas). Cechy te uzdalniają człowieka do bezinteresowności, zaangażowania na rzecz dobra wspólnego i współpracy (Babicki 2019, 196).

Kształtowanie postawy solidarności i sprawiedliwości społecznej w ramach edukacji dla zrównoważonego rozwoju ma promować dobra społeczne, takie jak: wolność i równość, dochód i bogactwo oraz to wszystko, co stanowi podstawę poczucia własnej wartości. Sprawiedliwość oznacza tutaj uczciwość, która przyznaje każdej osobie ludzkiej pełnię wolności i szans na godne życie. W świetle nauczania Kościoła katolickiego idea sprawiedliwości społecznej jest ściśle związana z ideą solidarności, określaną również „przyjaźnią”, „miłością społeczną". Sprawiedliwość społeczna wyrażająca się w postawie solidarności stanowi wybitnie chrześcijańską cnotę, która urzeczywistnia partycypację w większym stopniu w dobrach duchowych niż w materialnych. Papież Benedykt XVI nauczał, że sprawiedliwość wymaga uznania i poszanowania nie tylko praw jednostki, lecz także praw społecznych i całych narodów (Benedykt XVI 2009, 6). Jan Paweł II głosił zaś, że sprawiedliwość domaga się zapewnienia „podstawowego prawa narodów do istnienia i postępu" (Jan Paweł II 1991, 35). Postawa sprawiedliwości wyraża się w wewnętrznym przekonaniu jednostki o powinności poszanowania prawa drugiego człowieka do określonych wartości i dóbr, które przynależą do niego na mocy jego człowieczeństwa. W praktyce postawa sprawiedliwości będzie przybierała różne formy. W jednym przypadku może mieć charakter poszanowania dóbr osobowych, np. wolności, samodzielności, dobrego imienia itp. W innym przypadku może chodzić o bezwzględne poszanowanie zdrowia i życia drugiego człowieka (Babicki 2017, 134-137).

Papież Franciszek wzywa do rzetelnej edukacji w celu kształtowania postaw społecznych, które wyrażają się w powszechnym braterstwie i przyjaźni społecznej. Właśnie w edukacji papież widzi narzędzie wspierające człowieka w przygotowaniu go do 
myślenia i działania w warunkach ryzyka. Mówi bowiem: „Obowiązek wychowania, rozwój nawyków solidarności, zdolność do myślenia o życiu ludzkim w sposób bardziej integralny oraz duchowa głębia są konieczne, aby podnieść jakość ludzkich relacji, tak aby samo spoteczeństwo reagowało na istniejace $w$ nim nierówności, wynaturzenia i nadużycia ze strony sit gospodarczych, technologicznych, politycznych i medialnych. Istnieją wizje liberalne, które lekceważą tę ludzką kruchość i wyobrażają sobie świat odpowiadający pewnemu porządkowi, zdolny sam z siebie zapewnić przyszłość i rozwiązać wszystkie problemy" (Franciszek 2020, 115116). Dlatego widzi potrzebę, aby edukacja dostarczała ludziom, zwłaszcza młodym, wiedzy o przyczynach i skutkach nierówności społecznych oraz ubóstwa na podstawie zasady przyjaźni społecznej i braterstwa. Zauważa, że człowiek jest tak stworzony, iż nie spełnia się, nie rozwija i nie może znaleźć swej pełni inaczej, jak tylko „przez szczery dar z siebie samego". Oto tajemnica prawdziwej ludzkiej egzystencji, ponieważ „życie istnieje tam, gdzie jest więź, jedność, braterstwo; i jest życiem silniejszym od śmierci, kiedy jest zbudowane na prawdziwych relacjach i więziach wierności. Przeciwnie, nie ma życia tam, gdzie człowiek uważa, że należy tylko do siebie i chce żyć jak wyspa" (Franciszek 2020, 61). Może warto wzbogacić tę ofertę edukacyjną o perspektywę zrównoważonego rozwoju. Takie dążenia wynikają z potrzeby dalekosiężnego i rzetelnego przygotowania przede wszystkim młodego pokolenia do aktywnego funkcjonowania w życiu społecznym, ponieważ to właśnie młodzi ludzie mają budować przyszłość świata, opierając się na wartościach społecznych. Edukacja zatem powinna kształtować postawy aktywności, budzić dynamizmy tkwiące w jednostkach i grupach społecznych. Mówiąc językiem pedagogiki społecznej, trzeba budzić siły ludzkie i siły społeczne.

Pozytywnych odpowiedzi na pytania o kierunek rozwoju współczesnego świata można poszukiwać w koncepcji tzw. czynnika ludzkiego. Niezależnie od tego, jakby to banalnie nie zabrzmiało: przyszłość świata leży w rękach ludzi. Nie we wszystkich jednak rękach, bo nie każdy chce lub może być „aktorem społecznym", osobą czynną, aktywną, zaangażowaną. I to nie dlatego, że nie ma ku temu odpowiedniej motywacji, adekwatnego oglądu świata czy możliwości sprawczych. Idzie o ludzi przygotowanych „do rozwoju własnej osobowości, czyli kultury umysłu, kultury współżycia i współdziałania społecznego, odpowiedzialności i pracy" (Theiss 2016, 28). Chodzi tu o ludzi, którzy swoją aktywność opierają na niezbywalnej zasadzie miłości i pomocy bliźniemu. Miłości, która znajduje się u podstaw tego, co nazywamy „przyjaźnią społeczną”. Gdy miłość ta jest autentyczna, wówczas przyjaźń w obrębie społeczeństwa umożliwia prawdziwą powszechną otwartość (Franciszek 2020, 68). Papież Benedykt XVI podkreśla, że to właśnie miłość naznacza głębię ludzkiego życia, która w istocie jest „kryterium oceny decydującym ostatecznie o wartości lub bezwartościowości ludzkiego życia" (Benedykt XVI 2005, 15).

Horyzont myślenia i działania tak rozumianego człowieka społecznego daleko wykracza poza sprawy lokalne. Sięga problemów ponadlokalnych, o ile nie globalnych, bowiem „człowiek społeczny” opiera się nieprzyjaznym siłom, walczy z „dyktaturą globalnego świata”, „przemocą gospodarczą” osiągającą zysk kosztem ludzi. Po drugie, obecność czynnika ludzkiego jest gwarancją - w określonym stopniu - przyszłości alternatywnej, zbudowanej na podstawowych wartościach i respektujących te wartości. Po trzecie wreszcie, czynnik ludzki, widziany jako wyraz kreatywności, odpowiedzialności i autonomii, personalizuje się i przyjmuje postać „gospodarza cywilizacji globalnej" (Theiss 2016, 29).

Budowanie społeczeństw opartych na zasadzie solidarności społecznej jako uniwersalnego projektu moralno-etycznego skłania do refleksji i budzi wątpliwości. Na planie pierwszym pojawia się pytanie: czy jest to kolejna wizja "nowego wspaniałego świata” 
lub - mówiąc wprost - utopia? A może, pomimo wątpliwości, jest to lub może być rzeczywiste, realne narzędzie działania moralno-społecznego. Propagowanie solidarności globalnej i podnoszenie świadomości w zakresie współodpowiedzialności za jakość życia innych ludzi jest istotnym zadaniem edukacji na rzecz zrównoważonego rozwoju (Babicki 2019, 198).

Idea zrównoważonego rozwoju ujmuje problematykę dotyczącą życia współczesnego społeczeństwa i demokracji w globalnym świecie. W. Theiss przekonuje, że według papieża Franciszka „powrót do pierwotnego projektu demokracji to - z jednej strony - walka z ideami libertariańskiego indywidualizmu, jego hedonizmem i konsumpcjonizmem oraz aspołecznym charakterem, który powoduje, iż jednostki nie rozpoznają się [...] na szerszym horyzoncie braterstwa i dobra wspólnego, a także niezgoda wobec haseł neoutylitaryzmu, który rezygnuje ze sprawiedliwości społecznej, dobra wspólnego czy dobra ogółu. A z drugiej - rozbudowa chrześcijańskiego systemu wartości, na czele z integralną koncepcją człowieka, który cechuje się godnością, wewnętrzną relacyjnością i solidarnością, braterstwem i wspólnym działaniem z Drugim" (Theiss 2016, 31).

Pomimo różnych problemów współczesnego świata, których nie należy lekceważyć, papież pragnie w przesłaniu o braterstwie i przyjaźni społecznej wskazać wiele dróg nadziei. Zapewnia, że Bóg nadal sieje ziarno dobra w ludzkich sercach. Przypomina, że trwająca pandemia umożliwia nam dostrzeżenie i docenienie wielu ludzi dobrej woli, którzy zareagowali na lęk, poświęcając swe życie dla innych. „Byliśmy zdolni do uznania, że istnienia ludzkie są splecione i podtrzymywane przez zwykłych ludzi, którzy bez wątpienia współtworzyli decydujące wydarzenia naszej wspólnej historii: lekarzy, pielęgniarzy i pielęgniarki, farmaceutów, pracowników supermarketów, sprzątaczki, opiekunki, przewoźników, mężczyzn i kobiety pracujących dla zapewnienia usług społecznych i bezpieczeństwa, wolontariuszy, księży, zakonnice... zrozumieli, że nikt nie zbawia się sam" (Franciszek 2020, 38). Przesłanie papieża Franciszka płynące z encykliki Fratelli tutti ukazuje wartość życia autentyczną wiarą, która wyraża się w służeniu drugiemu człowiekowi - bliźniemu. Wskazuje na sposoby przeżywania wiary, które ułatwiają otwarcie serca na bliźnich, a to jest gwarancją prawdziwego otwarcia na Boga.

\section{Podsumowanie}

Zadaniem współczesnej edukacji jest przygotowanie jednostek i grup społecznych do funkcjonowania w szybko zmieniającym się i zglobalizowanym świecie. Budowanie społeczeństwa obywatelskiego, zdolnego brać odpowiedzialność za zrównoważony rozwój w wymiarze lokalnym i globalnym wymaga odpowiedniej edukacji. Kształcenie i wychowywanie społeczeństw w zakresie zrównoważonego rozwoju staje się jednym z kluczowych elementów w strategii radzenia sobie z globalnymi wyzwaniami. Dlatego celem edukacji w zakresie zrównoważonego rozwoju jest kształtowanie określonych postaw społecznych. Budowanie takich postaw można oprzeć na chrześcijańskim systemie wartości, w którym na czoło wysuwa się integralna koncepcja człowieka. W takim ujęciu człowiek charakteryzuje się godnością, wewnętrzną relacyjnością, solidarnością, braterstwem i gotowością do wspólnego działania.

Wiara, wraz z inspirującym ją humanizmem, musi podtrzymywać zmysł krytyczny wobec różnych przejawów niesprawiedliwości na świecie. Dlatego ważne jest, aby ludzie wiary w sposób bardziej bezpośredni i jasny ukazywali społeczny sens życia, braterski wymiar duchowości, przekonanie o niezbywalnej godności każdej osoby. Braterstwo nie jest jedynie wynikiem poszanowania swobód indywidualnych, ani nawet pewnej usankcjonowanej równości. Chociaż są to warunki sprzyjające, to nie wystarczają, aby braterstwo wynikało $\mathrm{z}$ nich jako rezultat konieczny. Braterstwo może wnieść do wolności i równości pewien wkład pozytywny, 
ponieważ jest ukierunkowane przede wszystkim na miłość (Franciszek 2020, 71).

Nadszedł czas współdziałania na rzecz realizacji celów humanistycznego rozwoju ludzkości, czyli zrównoważoną zmianę. Edukacja zmierzająca do budowania na świecie powszechnego braterstwa i przyjaźni społecznej daje możliwość podejmowania celów zrównoważonego rozwoju. Dzięki współpracy wszystkich ludzi dobrej woli cele zrównoważonego rozwoju przybliżają się do konkretnych ludzi, stając się ich własnym zadaniem do wykonania. Idea zrównoważonego rozwoju zyskuje ważnego sojusznika w postaci edukacyjnego wsparcia ze strony papieża Franciszka i jego wizji świata opartego na braterstwie i przyjaźni społecznej. Jest to wizja świata odwołująca się do obowiązku miłości bliźniego, troski o integralny rozwój człowieka i ostatecznie o jego zbawienie.

Z pewnością każda próba konfrontowania idei zrównoważonego rozwoju z nauczaniem społecznym papieża Franciszka, zawartym przede wszystkim w encyklice Fratelli tutti będzie zależała od przyjmowanego światopoglądu oraz wizji rozwoju człowieka i świata. Jednak tym, co łączy te dwie propozycje, to zatroskanie o dobro ludzkości i naszej planety. To wreszcie nadzieja, która mówi o rzeczywistości zakorzenionej w głębi istoty ludzkiej, bez względu na konkretne okoliczności i uwarunkowania społeczne, kulturowe czy ekonomiczne, w jakich żyje. Nadzieja mówi nam o pragnieniu, o dążeniu do spełnionego życia, „o chęci dotknięcia czegoś wielkiego, czegoś, co wypełnia serce i wznosi ducha ku wielkim rzeczom, jak prawda, dobro i piękno, sprawiedliwość i miłość. [...] Nadzieja jest odważna, potrafi spoglądać dalej, poza osobistą wygodę, poza małe pewności i zadowolenia, które zawężają widnokrąg, aby otwierać się na wielkie ideały, czyniące życie piękniejszym i godniejszym" (Franciszek 2020, 39). Troszcząc się o wspólny dom, jakim jest planeta, z nadzieją odwołujemy się do tego minimum powszechnego sumienia oraz niepokoju o wzajemną troskę, które mogą jeszcze trwać w ludziach. Dlatego należy łączyć wysiłki w budowaniu braterstwa i przyjaźni społecznej.

\section{Bibliografia}

Babicki, Zbigniew. 2017. „Sprawiedliwość społeczna w założeniach i działaniach sprawiedliwego handlu." Forum Pedagogiczne 7(2): 133-144.

Babicki, Zbigniew. 2019. „Wartości społeczne w edukacji dla zrównoważonego rozwoju." Forum Pedagogiczne 9(2/1): 193-206.

Benedykt XVI. 2005. Encyklika Deus caritas est. Dostęp 6.04.2021. http://www.vatican.va/content/ benedict-xvi/pl/encyclicals/documents/hf_benxvi_enc_20051225_deus-caritas-est.html.

Benedykt XVI. 2009. Encyklika Caritas in veritate. Dostęp 6.04.2021. http://www.vatican.va/content/ benedict-xvi/pl/encyclicals/documents/hf_benxvi_enc_20090629_caritas-in-veritate.html.

Burchard-Dziubińska, Małgorzata. 2014. „Idea zrównoważonego rozwoju”. W Zrównoważony rozwój - naturalny wybór, red. Małgorzata Burchard-Dziubińska, Agnieszka Rzeńca i Dominik Drzazga, 9-34. Łódź: Wydawnictwo Uniwersytetu Łódzkiego.

Christiansen, Drew. 2021. "Fratelli tutti and the Responsibility to Protect." Journal of Catholic Social Thought 18(1): 5-14.

Franciszek. 2014. „Przemówienie do uczestników światowego spotkania ruchów ludowych (28 października 2014)." L’Osservatore Romano wyd. polskie 11(366): 45.

Franciszek. 2019a. „Przemówienie podczas spotkania międzyreligijnego i ekumenicznego z młodzieżą (7 maja 2019)." L'Osservatore Romano wyd. polskie 6(413): 27.

Franciszek. 2019b. „Przemówienie do uczestników międzynarodowej konferencji na temat: Prawa człowieka we współczesnym świecie - osiągnięcia, zaniedbania, negacje (10 grudnia 2018)." L'Osservatore Romano wyd. polskie 1(409): 25.

Franciszek. 2020. Encyklika Fratelli tutti. O braterstwie $i$ przyjaźni społecznej. Kraków: Wydawnictwo „M”.

Jan Paweł II. 1988. Encyklika Sollicitudo rei socialis. Dostęp 6.04.2021. http://www.vatican.va/content/ john-paul-ii/pl/encyclicals/documents/hf_jp-ii_ enc_30121987_sollicitudo-rei-socialis.html. 
Jan Paweł II. 1991. Encyklika Centesimus annus. Dostęp 6.04.2021. http://www.vatican.va/content/ john-paul-ii/pl/encyclicals/documents/hf_jp-ii enc_01051991_centesimus-annus.html.

Kronenberg, Jakub, i Tomasz Bergier. 2010. Wyzwania zrównoważonego rozwoju w Polce. Kraków: Wydawnictwo Fundacja Sendzimira.

ONZ. 2000. Deklaracja Milenijna Narodów Zjednoczonych. Dostęp 24.01.2021. http://www. unic.un.org.pl/dokumenty/deklaracja_milenijna. doc.

Pilch, Tadeusz. 2013. „Wprowadzenie.” W Zagrożenia człowieka i idei sprawiedliwości społecznej, red. Tadeusz Pilch i Tomasz Sosnowski, 9-26. Warszawa: Wydawnictwo Akademickie Żak.

Rogalska-Marasińska, Anteta. 2017. Edukacja międzykulturowa na rzecz zrównoważonego rozwoju. Edukacja. Teorie ksztatcenia i wychowania. Łódź: Wydawnictwo Uniwersytetu Łódzkiego.

Skowroński, Antoni. 2006. „Zrównoważony rozwój perspektywą dalszego postępu cywilizacyjnego." Problemy Ekorozwoju 1(2): 47-57.
Światowa Komisja ds. Środowiska i Rozwoju. 1991. Nasza wspólna przyszłość. Warszawa: Państwowe Wydawnictwo Ekonomiczne.

Theiss, Wiesław. 2004. „Rozwój społeczny - kapitał ludzki - edukacja." W W trosce o mtodzież. Edukacja - praca - obywatelstwo, red. Jan Niewęgłowski, 98-114. Warszawa: Wydawnictwo Salezjańskie.

Theiss, Wiesław. 2016. „Solidarność globalna i zadania edukacji (Czytając Baumana).” W Teoretyczne i praktyczne konteksty edukacji globalnej, red. Zbigniew Babicki i Magdalena Kuleta-Hulboj, 17-36. Warszawa: Wydawnictwo UKSW.

Wielgosz, Przemysław. 2010. „Jak zmienić rozwój i pokonać nierówności." W Lokalnie - globalnie. Kluczowe zagadnienia studiów nad rozwojem, red. Gerard McCann i Stephen McCloskey, 5-8.Warszawa: Wydawnictwo Polskiej Akcji Humanitarnej. 